\author{
ФОРМУВАННЯ МЕТОДИЧНОЇ КОМПЕТЕНТНОСТІ МАЙБУТНІХ УЧИТЕЛІВ \\ МУЗИКИ У ПРОЦЕСІ ДИРИГЕНТСЬКО-ХОРОВОЇ ПІДГОТОВКИ \\ FORMATION OF METHODIC COMPETENCE OF FUTURE \\ MUSIC TEACHERS IN THE DIRECTIVE-CHOIR PREPARATION
}

УДК 378.011.3-051:78(0433)

DOI https://doi.org/10.32843/2663-

6085.2019.12-2.06

\section{Павлюк Н.М.,}

канд. пед. наук,

вчитель музичного мистецтва

Луцької гімназії № 4 імені

Модеста Левицького

\begin{abstract}
Наведено огляд публікацій, у яких досліджено застосування міжпредметних зв'язків упедагогіці, а також є певні досягнення у вивченні проблеми формування методичної компетентності майбутнього учителя музики. Розглянуто закономірності та принципи просресійної підготовки майбутніх учителів музики. Описано найбільш ефрективні шляхи удосконалення профресійної підготовки учителя музики. Окремо висвітлено основні фрактори організації творчої взаємодії студента у роботі з хоровим колективом. Ключові слова: методична компетентність, майбутні учителі музики, хорове диригування, профресійна підготовка.
\end{abstract}

Приведен обзор публикаций, в которых исследовано применение межпредметных связей в педагогике, а также есть определенные достижения в изучении проблемы формирования методической компетентности будущего учителя музыки. Рассмотрены закономерности и принципы просрессиональной подготовки будущих учителей музыки. Описаны наиболее эфффективные пути совершенствования просрессиональной подготовки учителя музыки. Отдельно освещены основные фракторы организации творческого взаимодействия студента в работе с хоровым коллективом.

Ключевые слова: методическая компетентность, будущие учителя музыки, хоровое дирижирование, профрессиональная подготовка.

An overview of publications, which explores the use of interdisciplinary connections in pedagogy, is presented, as well as some achievements in the study of the problem of the formation of the methodical competence of the future music teacher. Laws and principles of professional training of future music teachers are considered. The most effective ways of improving the professional training of music teacher are described. The main factors of organization of creative interaction of the student in work with the choir collective are separately highlighted.

Key words: methodical competence, future teachers of music, choral conducting, professional training.
Мета статті - розкриття суті ефективних змін у навчальному процесі, пошук нових фрорм і засобів, використання на заняттях із хорового диригування та практикумі роботи 3 хором сучасних методів і музичних технологій навчання; аналіз підготовки висококваліфікованих фрахівців за обраною спеціальністю, удосконалення профресійних умінь і навичок хормейстерської діяльності, співацької культури, фрормування у майбутніх фрахівців творчого підходу до педагогічної праці.

Постановка проблеми у загальному вигляді. Сучасна концепція освіти вимагає якісної підготовки майбутніх учителів музики, ефективних змін у процесі пошуку нових фрорм і засобів, використання на заняттях із хорового диригування, практикумі роботи $з$ хором сучасних методів і технологій навчання.

3 процесом підготовки сучасного учителя нині пов'язують оптимальний розвиток особистості, майбутнє людини і людства. Від рівня розвитку професійної компетентності вчителя залежить не лише соціально-етичне здоров'я країни, а й щастя кожної окремої людини. Тому важливо виявити педагогічно значущі резерви в підготовці учителя музики, задати інтенцію розвитку його методичного мислення. Це сприятиме підвищенню якості підготовки і фрормуванню методичної компетент- ності майбутніх учителів музики. У сучасній мистецькій освіті вирішення цього питання є особливо актуальним і потребує уваги педагогів і науковців.

Аналіз останніх досліджень і публікацій. Педагогічна наука має певні досягнення у вивченні проблеми фрормування методичної компетентності майбутнього учителя музики. Це наукові праці О. Берещенко, Н. Солової, Н. Сродник, 3. Стельмащук. Питання застосування міжпредметних зв'язків у педагогіці досліджувалися у роботах Т. Архіпової, Н. Гребенюк, І. Звєрєва, А. Єрьомкіна, Т. Іванченко, С. Ілларіонова, Т. Кирилова, В. Максимової, Г. Первушиної, В. Стешенко, Н. Тарарак. Однак недостатньо дослідженою залишається проблема оптимізації начального процесу диригентсько-хорової підготовки у виші та фрормування методичної компетентності майбутніх учителів музики у процесі вивчення курсу хорового диригування та практикуму роботи з хором.

Якість підготовки майбутніх учителів музики прямо залежить від якості робочих навчальних програм, навчальних планів, методичного забезпечення, рівномірного навантаження студентів, використання сучасних методів навчання.

Навчальний план $€$ основним документом начального процесу. Всі навчальні музичні дисципліни у навчальному плані перебувають у 
взаємозв'язку між собою і мають визначену послідовність вивчення загальних для всіх музичних дисциплін модулів.

Сучасна освіта базується на педагогічних законах, визначених у вітчизняних наукових дослідженнях. На таких законах базуються і закономірності та принципи професійної підготовки майбутніх учителів у сорері музичного мистецтва, зокрема: соціальної зумовленості мети, змісту і методів навчання і виховання характером діяльності; єдності та цілісності педагогічного процесу, який розкриває необхідність гармонічної єдності раціонального, емоційного, змістовного, операційного, мотиваційного компонентів педагогічного процесу; єдності та взаємозумовленості індивідуальної та колективної організації навчально-виховної діяльності; єдності та взаємозв'язку теорії та практики навчання [10].

Визначаючи проблему музичної педагогіки як сореру педагогічної науки і теорії музичного навчально-виховного процесу, О.В. Михайліченко окреслює такі закономірності музичного навчально-виховного процесу: єдність і взаємодію музичного виховання і загального розвитку особистості; зв'язок між рівнем музичного розвитку і характером її практичної музично-творчої діяльності; єдність загальної мети виховання особистості та конкретно музично-виховних задач; єдність процесів музичного виховання і музичного самовиховання; залежність музичного виховання від загального розвитку музичної культури та матеріальних можливостей суспільства; зв'язок між можливостями особистості та характером виховних впливів [10].

У дослідженнях провідних сучасних фрахівців у сорері музично-педагогічної освіти (Ю. Алієв, В. Живова, Б. Критський, Л. Рапацька, Г. Тенюкова, Г. Ципін та ін.) здійснюється пошук найбільш ефективних шляхів удосконалення професійної підготовки майбутнього учителя музики, а також дієвих способів подолання недоліків у діяльності фракультетів мистецьких дисциплін педагогічних ВНЗ. Найважливішим компонентом цих досліджень як теоретичного, так і практичного характеру є система аналізу процесу навчання й особливостей профресійної діяльності сучасного учителя музики.

Осмислення теоретичних засад фрахової підготовки майбутніх учителів музики на підставі аналізі досліджень Е. Абдулліна, Л. Арчажникової, А. Болгарського, Р. Верхолаз, А. Козир, О. Олексюк, Г. Падалки, О. Ростовського, О. Рудницької, Т. Смирнової та ін. [1-3; 6; 9-12] свідчать, що її метою $€$ розвиток особистісно-ціннісного ставлення до мистецтва, здатність до сприймання, розуміння і творення художніх образів, потреба в художньо-творчій самореалізації та духовному самовдосконаленні, забезпечення належного рівня профресійних умінь і готовності до самостій- ної музично-педагогічної діяльності. Саме у процесі фрахової підготовки майбутні учителі музики мають отримувати знання про сутність і зміст педагогічної діяльності, особливості її використання для максимально ефективної практичної роботи.

Виклад основного матеріалу. Термін «методична діяльність» у педагогічних працях визначається по-різному, зокрема як складова частина педагогічної діяльності, фрункції якої полягають в узагальненні досвіду навчання, виокремленні найбільш еорективних прийомів і способів навчання [7]. Автори протиставляють практичну і методичну діяльність, вважаючи, що остання рефлексивно надбудовується над першою. Часто поняття «методична діяльність» замінюється «методичною роботою», пов'язаною із самоосвітою, підвищення кваліфікації педагога у предметній сорері [13, с. 415]. Загалом у педагогічній літературі $є$ три погляди на методичну діяльність педагога:

1. постійна самоосвіта педагога, підвищення рівня дидактичної та методичної підготовленості до координування навчально-виховної роботи, освоєння найбільш раціональних методів і прийомів виховання і навчання студентів, обмін і передання накопиченого педагогічного досвіду;

2. підвищення теоретичного i практичного рівня педагога в конкретній галузі знань (у цьому підході не враховується специфріка методичної та навчальної діяльності 3 навчальними дисциплінами, а терміни «методична діяльність» і «навчальна діяльність» використовуються як синоніми);

3. активна участь у семінарах, круглих столах, конореренціях, здійсненні наукових досліджень, присвячених актуальним питанням розвитку профресійної освіти [8].

Методична діяльність педагога - це самостійний вид його професійної діяльності з подальшого вдосконалення свого педагогічного потенціалу, моделювання, проектування, конструювання, прогнозування та впровадження педагогічно корисного дидактичного забезпечення процесу навчання в освітню практику, що дає змогу здійснювати координацію навчальної діяльності окремої дисципліни або циклу дисциплін [8]. За значущістю методична діяльність посідає третє місце після викладання навчальної дисципліни і виховання. За всього різноманіття методик навчання, їх диференціації, різноплановості змісту навчання різним навальним дисциплінам у різних освітніх системах є загальні теоретичні основи виконання, загальна структура цього виду професійної діяльності педагога, основних процедур виконання методичних розробок.

Отже, методичну діяльність майбутнього учителя музики можна визначити як цілеспрямовану профресійну діяльність, пов'язану зі здійсненням, 
пізнанням і перетворенням практики навчання музиці з урахуванням і на підставі наукових досягнень у сорері музичної педагогіки. Відтак об'єктом методичної діяльності майбутнього учителя музики є орормування методичної компетентності та посилення диригентсько-професійної якості освітньо-кваліфрікаційних знань, навичок, умінь, a саме: диригентських вокально-хорових, історико-теоретичних, художньо-культурних, інструментально-виконавчих, концертно-відтворюючих, аналітико-оцінювальних, творчо-пошукових, концертно-відтворюючих, аналітико-оцінювальних, творчо-пошукових, організаційно-методичних. У взаємодії з предметами, що входять до спеціальності, потрібно фрормувати соціально-активну, гуманістичну з боку своїх світоглядних принципів, художньо-творчу, гармонійно-розвинену особистість, котра здатна опанувати складну синтетичну систему музично-педагогічних знань, навичок, умінь із практичною реалізацією їх в особі вчителя музики, керівника шкільних хорів загальноосвітньої школи. До функцій методичної діяльності педагога можна віднести аналітичну; проектувальну, пов'язану з перспективним плануванням і розробкою змісту освіти, управлінням навчальною діяльністю; конструктивну, яка включає дії, пов'язані 3 плануванням майбутнього заняття; нормативну, котра пов'язана 3 визначенням розробкою дидактичного забезпечення і сприяє дотриманню освітніх стандартів, вимог навчальних програм, умов здійснення цілісного педагогічного процесу в конкретному навчальному закладі; дослідницьку. Отже, фрормами представлення методичної майстерності у практиці є її узагальнення в різних публікаціях, відкриття власної науково-методичної системи тощо.

У контексті вищесказаного методичне мислення - це «особливий вид когнітивної діяльності, що виявляється в методично осмисленому використанні положень педагогіки та психології у навчанні та вихованні майбутніх учителів музики, освоєнні, створенні та застосуванні нових педагогічних засобів» [4]. Таке визначення дає підстави зробити висновок про два види професійної методичної діяльності майбутнього учителя музики, перший із яких пов'язаний з умінням успішно вирішувати методичні завдання, тобто гнучко застосовувати отримані знання для реалізації цілей навчання відповідно до методичної теорії та конкретних умов навчання, а другий вказує на необхідність інтелектуальної активності, тобто здійснення майбутнім учителем музики дослідницьких пошуків із метою підвищення свого профресійного рівня.

Методична культура складається з чотирьох елементів: 1) знання про всі компоненти процесу навчання: цілі, засоби, об'єкти, прийоми, про себе самого як майбутнього учителя музики; 2) досвід у вигляді освоєних прийомів навчання, на основі чого здійснюється репродукція методичної культури; 3) творче перетворення і перенесення прийомів у нові умови, тобто продукування нового в навчанні у межах власного досвіду; 4) досвід емоційного ставлення до професійної діяльності. Це дає змогу виокремити три ріні профресіоналізму: рівень грамотності (оволодіння системою методичних знань, знань наукових, а не емпіричних, бо тільки в цьому разі «грамотність» може слугувати основою вищих рівнів); рівень ремесла (володіння системою методичних прийомів, навичок, тобто досвідом роботи); рівень майстерності (володіння системою методичних умінь), які відповідно співвідносяться 3 елементами «знання», «досвід», «творчість», а в особистісному плані - 3 трьома підструктурами комунікативної структури особистості: пізнавальною, емоційно-оцінювальною, діяльнісною.

3 методичним мисленням тісно пов'язана методична компетентність, щодо якої у світовій практиці (Білій книзі, розробленій Європейською комісією, 1996; Меморандумі з освіти впродовж життя, 2000; Плані дій Євросоюзу та Ради Європи, 2002) широко використовуються поняття «ключові компетентності», що характеризуються багатофрункціональністю, надпредметністю, міждисциплінарністю і багатовимірністю. Саме методична компетентність майбутнього учителя музики забезпечує результативність процесу навчання, оскільки дає змогу з погляду науки визначати і реалізовувати принципи, зміст, фрорми., методи і засоби навчально-педагогічної діяльності.

Методична компетентність включає вміння майбутнього учителя музики здійснювати традиційну педагогічну діяльність, тобто відбір і композицію навчального матеріалу; планування і побудову педагогічного процесу; проектування навчальнометодичної бази педагогічного процесу; виконання системи дій, спрямованих на включення учнів у різні види діяльності; створення колективу й організацію спільної діяльності; становлення педагогічно доцільних відносин майбутнього учителя музики з учнями, представниками громадськості, батьками; а також умінням проектувати та конструювати педагогічні інновації, тобто професійно відбирати зміст інновацій, проектувати реалізацію цього змісту через застосування сучасних педагогічних технологій, прогнозувати очікуваний результат, який може бути отриманий у ході реалізації інновацій, описувати критерії оцінювання ефективно спроектованої інновації. Відтак логічно припустити, що фракторами сталого розвитку методичної компетентності майбутнього учителя музики є: організація науково-методичної роботи й участь майбутнього учителя музики у ній; безперервне вдосконалення кваліфікації майбутнього учителя музики в умовах професійної діяльності та його 
професійне самовиховання (самоінформування, самоспонукання, самоорганізація); перспективність методичної роботи; конкретність і актуальність змісту методичної роботи; різноманітність формм і методів методичної роботи.

Зв'язок методичної компетентності майбутнього учителя музики з методичним мисленням полягає у взаємозалежності міри їх ссрормованості. Отже, методичне мислення майбутнього учителя музики - це особливості розумової діяльності, зумовлені характером і видом професійної праці, це певне бачення викладачем процесу конструювання й організації навчання у процесі диригентсько-хорової підготовки. У методичному мисленні як багаторівневому явищі відображаються конкретні настанови, психолого-педагогічні знання, просресійні якості особистості, способи розумових і практичних дій.

Найвищим проявом усвідомлення студентами необхідності використання методики хормейстерської підготовки $€$ успішне застосування знань на практиці, адже їх не можна ні засвоїти, ні зберегти поза діяльністю. Тому в процесі практичних занять із диригування, хорового класу, практикумі роботи 3 хором потрібно акцентувати увагу не тільки на засвоєнні знань, а й на оволодінні студентами основними методичними вміннями у контексті розвитку професійно-особистісних якостей.

у срормуванні методичної компетентності майбутніх учителів музики в процесі диригентсько-хорової підготовки увага приділяється удосконаленню диригентської техніки, розвитку музично-слухових уявлень і музичних здібностей. У процесі практичних занять із хорового диригування, хорового класу, практикумі роботи з хором акцентується увага на оволодінні студентами методичними вміннями у контексті розвитку професійно-особистісних якостей. Використовуються такі методи і прийоми: розповідь, пояснення, методи показу, спостереження й аналіз роботи 3 хором викладача-керівника хорового колективу та студентів, метод обговорення теоретичного матеріалу (у фрормі міні-лекцій), моделювання ситуацій репетиційної роботи з хором, активізації комунікативного потенціалу керівника хору, метод конкретних ситуацій, ігрові методи. Ці методи $€$ поширеними у практиці професійної підготовки і належать до методів навчання, які впливають на формування не тільки пізнавальних, а й особистісних якостей. Вони також сприяють вихованню системного мислення, дають цілісне уявлення про професійно-педагогічну діяльність, навчають практичної роботи, дають змогу розвиватися та формуватися професійно-особистісним якостям студентів.

Диригентську техніку розглядають як своєрідний аналог людської мови у значенні знакової системи мислення і висловлювання. Поштовхом для розуміння значення диригентської техніки стає саме діалектична цілісність технічного та художнього рівнів виконавства, усвідомлення процесу звукового втілення виконавського задуму. Функціонування внутрішніх дій диригента, уявне музикування, зіставлення його 3 реальним звучанням хору чи оркестру і необхідне коригування звучання дають змогу диригенту не просто передавати зовнішню форму твору (технічний рівень виконавства), а й осягнути глибинну суть музичних образів, створити індивідуальну виконавську інтерпретацію (художній рівень).

Вивчення хорового твору в індивідуальному класі хорового диригування $€$ тривалим і структурно складним процесом. Специфрічна ускладненість діяльності учителя музики як диригента-хормейстера, на відміну від інших музикантів інших спеціальностей, у передрепетиційний період полягає у відсутності об'єкта впливу. Особливість диригентської діяльності передбачає такий рівень підготовки керівника хору, який дає змогу створити ідеальну модель майбутнього звучання партитури до репетиції. Розвиток здатності до уявного моделювання художньо-образного звучання хорового твору ж однією з найскладніших проблем у диригентській педагогіці.

Аналіз хорової музики $€$ обов'язковим для срахової підготовки майбутнього учителя музики як диригента-хормейстра. Теоретично-аналітичний підхід до музики дає змогу сорормувати осмилену, об'єктивно аргументовану інтерпретацію, наблизитися до композиторського задуму, а також дає можливість виконавцеві розкрити свою творчу індивідуальність. До важливих структурних елементів виконавського аналізу хорового твору належать загальні історико-стилістичний, літературно-текстовий, музичо-теоретичний, вокальнохоровий і власне виконавський аналіз.

На індивідуальному занятті викладач-диригент націлює студента на те, щоб він спостерігав міміку і жести, особливо рухи пальців, які у диригентському жесті мають величезне значення. Жести відображують відтінки музичного розвитку мотивів, фрраз, періодів. Диригентські жести мають чітко визначені емоційно-смислові визначення, що виявляють «підтекст» твору.

Проблема адаптації до хорового звучання одна з найскладніших у диригуванні. Багатофрактурність звуку хорових голосів, велика кількість фрактурних елементів творів не дає змоги хормейстеру помітити окремі помилки, осягнути художній бік виконання. Означена проблема актуалізує важливість фрормування високорозвиненої слухової уваги студента в курсі «Диригування». Позитивних результатів можна досягнути за умови, якщо у процесі диригентсько-технічного втілення хорових творів слухова увага студента спрямовуватиметься з одного елемента музичної тканини 
на інший. Систематичне просування в такому напрямі дасть змогу вирішувати складні завдання. Завдяки дифреренціації фрункцій рук можна добитися збалансованості звучання окремих фрактурних пластів хорового твору, необхідного тембрального забарвлення голосів і твору загалом, коригування хорового строю та характеру співацького дихання.

Хоровий клас - одна 3 профілюючих дисциплін у підготовці майбутнього учителя музики. На заняття хорового класу студенти не лише опрацьовують професійні знання та навички, які допомагають їм у майбутньому працювати, але й знайомляться з кращими зразками хорової літератури на практиці.

У системі диригенсько-хорових дисциплін хоровий клас розглядається у сукупності таких елементів, як: а) хоровий клас як модель фрормування хорового диригента; б) концепція репертуару хорового колективу як передумова фрормування його виконавського стилю; в) встановлення загальних рис репетиційного процесу; г) розспівування хору як передумова фрормування вокальнохорової майстерності колективу; д) класиорікація форм роботи 3 хоровим колективом.

«Хоровий клас як модель лабораторії фрормування хорового диригента» включає такі елементи: хоровий колектив як систему високого рівня організації; основні принципи функціонування хорового колективу; його загальні функції, взаємодію двох напрямів роботи студента в хоровому класі; узагальнення поняття про хоровий колектив.

Розглядаючи хоровий колектив вищого навчального закладу як своєрідну лабораторію фрормування хорового диригента, слід наголосити, що спектр впливу хорового мистецтва значно ширший, ніж вважалося раніше, оскільки якості, сфрормовані у процесі занять, переносяться на інші види діяльності людини. Хоровий колектив, набуваючи рис найдосконалішого музичного інструменту, є системою високого рівня організації. Це виявляється в тому, що хоровий колектив $€$ виразником не тільки колективного, а й індивідуального мислення. Не випадково фрілософи відносять хоровий спів до найважливіших компонентів фрормування національного характеру в його загальних, психологічних і в окремих, найбільш типових рисах менталітету.

Організація навчальної діяльності майбутніх учителів музики передбачає: 1) вплив на могутню copepу 3 метою підвищення занять диригування і хоровому класі, потреби не тільки фрормуванні хормейстерських вмінь і навичок, а й у розвитку та фрормуванні професійно-особистісних якостей; 2) взаємодію компонентів навчально-виховного процесу, тобто теоретичні знання, вміння і навички та формування профресійно-особистісних якостей має бути комплексним процесом; 3) включення майбутнього вчителя музики як диригента-хормейстера у ситуацію фрахового визначення, само- ствердження, 3 метою ефективного вирішення поставлених завдань хормейстерської підготовки.

Слід зазначити, що фрормування мотивації студентів неможливе без актуалізації емоційної сорери. Емоційне ставлення до хормейстерської діяльності майбутнього учителя музики сприяє розвитку якостей, даючи можливість торкнутися глибинних інтересів особистості, її духовних потреб. Інтерес до хормейстерської діяльності може бути загальним, недиференційованим (тобто студенту цікаві всі жанри хорової музики, його однаково хвилюють загальні методи роботи 3 хором незалежно від типу та виду хору), або до одного якогось напрямку роботи (наприклад, до роботи 3 дитячими колективами чи однорідним або мішаним складом). На інтерес можуть впливати нахили, здібності, деякі риси характеру чи темпераменту студента, що становлять певну цінність для особистості.

У студентів виробляються різні шляхи мотивації до орормування професійно-особистісних якостей. Так, з одного боку, мотивація полягає у виробленні у студентів ідеалів, взірців того, якими мають бути мотиви щодо формування якостей. Майбутній вчитель усвідомлює ці мотиви як еталони, за якими він оцінює власну діяльність, у процесі якої визначаються мотиви, що діють реально.

Стимулювання інтересу студентів до хорового мистецтва, спонукання до вивчення стилів керівництва хоровим колективом, реалізація зазначених завдань здійснюється внаслідок проведення різних типів занять. Це, зокрема: перегляд відеозаписів хорових професійних колективів, відвідування репетицій сучасних відомих колективів, взаємозв'язок методів і прийомів репродуктивного і пошукового характеру: розповіді про життя і творчі здобутки видатних хормейстерів, спілкування 3 диригентами хорових колективів, відвідування майстер-класів.

Для того, щоб провести повноцінне диригентське заняття, необхідно якісно побудувати його, тобто створити таку структуру, яка б найбільше сприяла розвитку професійно-особистісних якостей майбутнього учителя музики як диригента-хормейстера. На цьому етапі на заняттях із хорового диригування необхідно поєднувати різні види диригентської хорової діяльності, охоплюючи не тільки формування мануальної техніки, принципи роботи з різними хорами, творами, а й розвиток музичної та загальної культури молодого керівника хорового колективу. Отже, складна структура заняття виходила за межі оволодіння суто диригентськими знаннями й уміннями, а також передбачала розвиток особистості фрахівця. Зрозуміло, що негативні риси характеру хорового диригента (невміння організувати себе, некоректність у відносинах зі співаками, неповага до хору тощо) негативно позначаються на стосунках із творчим колективом. Ці питання пови- 
нні бути в полі зору викладача, котрий проводив індивідуальну навчально-виховну роботу з кожним майбутнім хормейстером, розвиваючи позитивні риси їхнього характеру.

На індивідуальному занятті з хорового диригування поєднуються навчання і виховання студента, його формування як особистості лідера-керівника. Лідерські якості пов'язані, на нашу думку, з особливостями майбутнього фрахівця. Як відомо, лідер у перекладі з англійської мови - це керівник. Лідерство - механізм інтеграції діяльності групи через відносини домінування і підпорядкування. Прояв лідерських якостей вбачається у виконанні індивідом ролі організатора і координатора спільних зусиль усіх членів колективу. Взаємини лідера - хорового диригента та членів хорового колективу поділяються на авторитарні, демократичні та ліберальні, за визначенням А. Козир [5], тим самим визначаючи стиль керівника хорового колективу. Завдання фрормування лідерських якостей у майбутнього керівника хорового колективу вирішуються у навчально-виховному процесі на індивідуальних заняттях впродовж усього періоду навчання.

Висновки. Актуалізація процесу формування методичної компетентності майбутніх учителів музики у процесі диригентсько-хорової підготовки неможлива без створення установки на усвідомлювання та коригування власних якостей. Це вимагає розвитку професійної самосвідомості (здатності сприймати себе як активну особистість); накопичення теоретичних знань і практичних якостей хормейстерської діяльності (профресійно-значущої якості майбутнього учителя музики як диригента-хормейстера).

У послідовному принципі міждисциплінарних зв'язків містяться важливі резерви подальшого вдосконалення навчально-виховного процесу. Міждисциплінарні зв'язки об'єднують музичні дисципліни й утворюють єдиний навчальний цикл у вигляді багаторівневої системи.

Суміжні до хорового диригування та практикуму роботи 3 хором музичні дисципліні (сольфреджіо, основний інструмент, постановка голосу, хорознавство й аранжування, педагогічна практика, методика музичного виховання) безпосередньо фрормують методичну компетентність майбутніх учителів музики, надаючи знання, уміння, навички, які завдяки зв'язкам поглиблюються, інтегруються, систематизуються, узагальнюються й об'єднуються в єдину педагогічну систему.

\section{БІБЛІОГРАФІЧНИЙ СПИСОК:}

1. Абдуллин Э.Б., Ванилихина О.В., Морозова Н.В. Методологическая культура педагогамузыканта. Москва : Изд. центр «Академия», 2002. 272 c.

2. Арчажникова Л.Г., Рапацкая Л.А. Развитие теории высшего музыкально-педагогического образования. Советская педагогика. 1989. № 5. С. 65-71.

3. Болгарский А.Г. Задачи профессиональной подготовки будущего учителя музыки в условиях реформы школы. Совершенствования профрессиональной подготовки учителя музыки в условиях рефрормы школы : сборник научных трудов / ред. кол. : А.Г. Болгарский и др. Киев : КГПИ, 1988. С. 3-7.

4. Коваленко І.Г. Теоретичні та практичні аспекти підготовки студентів Інститутів Мистецтв до керівництва хоровими колективами ( для студентів та викладачів вищих навчальних закладів). Київ : Видавництво Національного педагогічного університету імені М.П. Драгоманова, 2012. 122 с.

5. Козырь А.В. Формирование стиля педагогического руководства хоровым коллективом (на материале муз-пед. фракультетов пединститутов) : автореф. дис. ... канд пед. наук : 13.00.01 / Киев. гос. пед. ин-т имени А.М. Горького, 1987. 21 с.

6. Козир А.В. Професійна майстерність учителів музики: теорія і практика формування в системі багаторівневої освіти : монографія. Київ : НПУ імені М.П. Драгоманова, 2008. 378 с.

7. Кузьмина Н.В. Методы исследования педагогической деятельности. Ленинград : Изд-во Лгу, 1970. $114 \mathrm{c}$.

8. Скибицкий Э.Г., Толстова И.Э., Шефель В.Г. Методика профессионального обучения. Новосибирск : НГАУ, 2008. 166 с.

9. Михайличенко О.В., Рудницька О.П. Музыкальная педагогика как отрасль педагогической науки и теории музыкального учебно-воспитательного процесса. Мистецька освіта в Україні: теорія і практика / за ред. О.М. Михайліченко. Суми : СумДПУ ім. А. Макаренка, 2010. 255 с.

10. Олексюк О.М. Музична педагогіка : навчальний посібник. Київ : КНУКіМ, 2006. 188 с.

11. Падалка Г.М. Українська фрілармонія для дітей та юнацтва: Проблеми модернізації музичної педагогічної освіти. Мистецтво і освіта. 1998. № 1. С. 7-10.

12. Ростовський О.Я. Профресійна підготовка майбутніх учителів музики: проблеми і перспективи. Наукові записки Тернопільського університету. Серія : Педагогіка. 2001. № 2. С. 15-22.

13. Рудницька О.П. Музика і культура особистості: проблеми сучасної педагогічної освіти : навчальний посібник. Київ : ІЗМН, 1998. 248 с.

14. Современный словарь по педагогике / сост. Е.С. Рапацевич. Минск : «Современное слово», 2001. 928 C. 